\title{
A Braided Narrative for Digital History
}

\author{
Lincoln A. Mullen \\ George Mason University \\ lincoln@lincolnmullen.com
}

This is a preprint of a chapter to appear in Debates in the Digital Humanities 2019, edited by Lauren F. Klein and Matthew K. Gold (University of Minnesota Press, forthcoming 2019), http://dhdebates.gc.cuny.edu/. This preprint has been posted with the permission of the editors. Please cite the forthcoming version.

\begin{abstract}
Computational digital historians have tended to elucidate their methods rather than advance interpretative arguments. While this attention to method is salutary, given the absence of methodological discussion in history generally, it is not clear how computational historians can advance historical arguments while also explaining methods. Drawing on a classic essay by David Hackett Fischer, "The Braided Narrative: Substance and Form in Social History," this essay proposes a model for argumentative writing in computational digital history. Rather than using models such a methods section drawn from other disciplines, a braided narrative weaves together methodology and interpretation. The two strands strengthen one another when digital historians can elucidate how their methods and interpretations are mutually constitutive.
\end{abstract}




\title{
A Braided Narrative for Digital History
}

\author{
Lincoln A. Mullen, George Mason University
}

\begin{abstract}
"It is a rare monograph today which is not festooned with lorenz curves and punctuated with numbers." That is how the historian David Hackett Fischer described the current state of his discipline in 1976 (132). Substitute network diagrams for Lorenz curves and blog posts for monographs, and one would have a fair description of the current state of scholarship in digital history.

It is apparent to observers of digital history, as it was apparent when Fischer commented on the rise of social history, that digital history trades in methods more than most other forms of history. Digital historians delight in writing and reading tutorials on how to use tools and software for their research and teaching; they teach workshops on those methods and line up to attend them. Blog posts in the field more often recount the steps that the researcher took than the conclusions that he or she came to. And digital history is fortunate to have a burgeoning methodological literature for humanities computing, including The Programming Historian, ${ }_{3}^{1}$ The Historians' Macroscope, and several books on specific programming languages. $^{3}$
\end{abstract}

Amidst this enthusiasm for methods in digital history, one might reasonably conclude that something has gone amiss, that methods have won out over interpretations and argumentation. Tom Scheinfeldt argued in 2012 that it is a positive change that digital historians "traffic much less in new theories than in new methods" (Scheinfeldt 2012a). Still, Scheinfeldt thought that while digital history needed more "time to experiment and even ... time to play," sooner or later "digital humanities must make arguments" (Scheinfeldt 2012b). In reaction to the gap between digital history's promise and its payoff, Cameron Blevins has argued that when it comes to "argument-driven scholarship ... digital history has largely overpromised and underdelivered" (Blevins 2016). Blevins makes the point that digital historians have written extensively about their methods but not actually employed them to make many substantive interpretations. In the face of widespread skepticism among non-digital historians that DH methods will ever pay off, Blevins and others have urged digital historians to create disciplinary-specific argumentation and interpretation. We might add to these critiques that historians have long prized the art of storytelling and have often focused on the particulars of

\footnotetext{
1 http://programminghistorian.org/

2 http://www.themacroscope.org/2.0/

$3 \quad$ For example Jockers (2014) and Arnold and Tilton (2015).
} 
history, including individual lives, as a mode of communicating the complexities of the past. Yet digital history (at least, computational history rather than digital public history) has tended to pull historians towards the abstract and the generalizable at the expense of storytelling and historical particulars.

While digital historians do write about methods more than they make arguments, most historians have the opposite problem. Historians have an unhealthy tendency to hide their methods, and the discipline as a whole has no real venue to discuss methodology. Though they rarely write about them, historians' work is defined by the various methodologies that they practice, since social history, political history, cultural history, and now digital history are rather different communities of practice which have come to rather different interpretations of the past. Instead, the problem is that historians do not write about or debate their methods with the same transparency and rigor that they do their interpretations. So-called "methods" classes in graduate school often conflate discussions of theories or outstanding books in the field with learning how to actually conduct research. Journal articles and books rarely discuss their methods explicitly, and there are no high-profile journals in historical methodology. The result is that digital historians have been writing about their methods when the broader discipline has not.

We have, then, a deficiency of interpretation in digital history and a deficiency in explicit methodological discussion in history generally. These commensurate absences are puzzling, since our methods produce our interpretations. We must find a way of writing digital history that puts historical interpretation and argumentation at the center, while giving due weight to explaining the methodology that led to those results. Neither digital history as currently practiced nor the methodological silence of the broader discipline is a sufficient model for digital historians' work.

This problem is, mutatis mutandis, similar to the one that historians faced in the 1970s. In an essay titled "The Braided Narrative: Substance and Form in Social History," Fischer observed that historians prior to the 1970s had dealt with history as a "narrative craft," made possible because of a focus on elites (110). The new social historians, though, saw history as not "a story-telling but a problem-solving discipline" (112). The turn away from studying the kinds of socially or politically prominent figures who left behind large collections of correspondence or literary sources required using sources such as census or probate records that were tractable only to new methods expressed in "empirical findings." Empiricism made that kind of history "increasingly a mathematical science, which speaks in symbols and numbers" (113). The parallels to digital history are clear, since digital history often deals with a greatly expanded base of primary sources, often values empirical 
results over theory, and (at least in computational history) depends on methods that are statistical or algorithmic.

In his essay, Fischer aimed to provide a way of reconciling social historians' newfound empiricism with their narrative tradition. Fischer argued for "the incorporation of statistics in a text" and opposed putting statistics in an appendix on the grounds that the "two must be combined in a single expressive act" (131-33). This way of writing Fischer termed a "braided narrative," in which the scholar wove analysis with narrative instead of separating the two. A section analyzing, for instance, social class would be succeeded by a section narrating the lives of actual people living within those structures. The key point was that two modalities of writing history, analysis and narrative, were to be integrated in a complex prose form suitable to the task of maintaining history as a both an empirical and a story-telling discipline.

Digital historians can adapt Fischer's braided narrative for their own purposes. Where Fischer envisioned a braided narrative of empiricism and storytelling, digital historians can braid together interpretations and discussion of methodology. Fischer's model is a prompt for asking what way of combining narrative or argumentation and digital methods is most likely to be successful.

There is no shortage of options for how we might write. One approach is to borrow a page from the sciences or the quantitative social sciences and include a distinct methods section. This approach is often adopted in the relatively new Journal of Cultural Analytics (e.g. Jockers and Kirikkoff 2016). Another option, common among grant-funded projects, is to write a white paper that explains methodology. Computational projects should (and increasingly but by no means universally do) make their code and data available and reproducible in an open-source repository, such as GitHub ${ }^{5}$ and figshare. The blog of an individual scholar or a project blog is another way of explaining methodology. Sometimes scholars publish two distinct articles, one on interpretations and the other on methods (e.g., Cordell 2015 and Smith et al. 2015). ${ }^{7}$

Yet these options are inadequate because they all separate methods and the interpretations that result from them. Blogs are sometimes the place where scholarship actually happens, which the journal article merely sums up, but that implies a disjunction between the iterative process of blogging and the conclusions presented in the article or book. The code repository is only available to those who

$4 \quad$ Other scholars have also found the roots of digital history in social history or found instructive parallels between the two movements (Hockey 2004; Thomas 2004).

5 https://github.com/

6 https://figshare.com/

7 Digital literary scholars have gone much further than digital historians in incorporating computational methods and interpretive questions. See for example Goldstone and Underwood (2014). 
are sufficiently literate in the programming language used. Furthermore, the details of the code are crucial, but they can obscure the patterns of problem solving, and the abstractions that the code actually implements. The white paper is peculiar to the grant process and not likely to be adopted by non-grant projects. Finally, the separate methods section following the model of the sciences is a poor fit for historical research. It implies that history is a kind of empirical, hard science.

A braided narrative for digital history would instead weave together discussions of methods with the process of interpretation. A section explaining the questions that a historian is trying to ask could be followed by an explanation of how a machine-learning algorithm performs a particular transformation (cf. Schmidt 2016). For example, a discussion of the methodology of word-embedding can be followed by the interpretations drawn from applying that technique to a corpus of literature (as in Gavin et al. 2017). A historian, to take an example from my MA student Kim Nettles, might explain how word-embedded models place terms in a multidimensional space to preserve many kinds of relationships to other terms, then go on to explore how nineteenth-century racialized discourse plotted on to different dimensions of black versus white, insider versus outsider. The two strands of the braid here are methodology and interpretation. The key to this strategy is to find an assumption made by the method (words can be embedded in multidimensional space) that matches the historical question (racialized discourse was multidimensional).

Digital historians have a firm justification for thinking that they can find shared assumptions between historical interpretations and digital methods because algorithms only work well when they are well-matched to assumptions about our data and sources (Wolpert and Macready 1997; Robinson 2015). This implies that any good digital historical work will have a compatibility--even a harmony--between the methods applied and the sources and conclusions. We can use this harmony as the basis for combining discussion of methods with discussion of interpretations into a counterpoint, where methodology and interpretations are not discrete but mutually constitutive.

In my own work, I have found that identifying the assumptions common to the digital methods that I employ and the historical questions that I ask is the best way to blend discussion of methods and interpretations. For example, Kellen Funk and I have been working on the Field Code, a legal code of civil procedure drafted in New York in the late 1840s and subsequently adopted with modifications by most American states. (For a summary of this project, see Funk and Mullen 2018.) As we wrote up our research, we alternated between explaining how the minhash/locality-sensitive hashing algorithm can compare the similarities of documents (Leskovec et al., ch. 3) to interpreting the patterns of similarities among the Field Code states, between explaining how affinity propagation clustering groups similar documents by finding an "exemplar" document (Frey et al. 2007) to arguing about the significance of exemplar sections of the code dealing with debt collection and racialized exclusions of witnesses. While we initially contemplated a 
methods section modeled on a scientific paper, we found that we could braid a discussion of our interpretations with our computational historical research, because our computational work produced the accurate historical interpretations when it depended most closely on what we knew from traditional sources.

Finding such congruence between methods and sources is only one strategy for crafting a braided narrative. While that specific strategy might not be applicable in every instance, the more important point is how the structure of writing can aid the task of combining methods and interpretation. Adapting a braided narrative recognizes that our most powerful technology for integrating divergent approaches remains prose. Digital history has often been willing to experiment with forms of scholarship beyond the journal article, book, and blog post, even if this experimentation has gone by the wayside in recent years. But none of these experiments has overthrown - and they may in fact have underscored-the importance of using prose to explain scholarship, even if that scholarship includes newer modes of working such as visualizations.

Prose remains our best method for achieving a synthesis of methods and argumentation, yet digital historians need a way to structure their prose that suits their purposes. The braided narrative proposed by our social historical forebears proves to be a useful model for writing digital history that explains its methods but also produces scholarly interpretations.

Bibliography

Afanador-Llach, Maria José, Antonio Rojas Castro, Adam Crymble, Víctor Gayol, Fred Gibbs, Caleb McDaniel, Ian Milligan, Evan Taparata, Amanda Visconti, and Jeri Wieringa, eds. The Programming Historian. 2nd ed., 2017.

http://programminghistorian.org/

Arnold, Taylor, and Lauren Tilton. Humanities Data in R. Springer, 2015. http://link.springer.com/10.1007/978-3-319-20702-5

Blevins, Cameron. "Digital History's Perpetual Future Tense." In Debates in DH 2016, ed. Matthew K. Gold and Lauren F. Klein, online edition (University of Minnesota Press, 2016), http://dhdebates.gc.cuny.edu/debates/text/77

Cordell, Ryan. "Reprinting, Circulation, and the Network Author in Antebellum Newspapers." American Literary History 27, no. 3 (September 1, 2015): 417-445. https://doi.org/10.1093/alh/ajv028

Fischer, David Hackett. "The Braided Narrative: Substance and Form in Social History." In The Literature of Fact: Selected Papers from the English Institute, edited by Angus Fletcher, 109-33. New York: Columbia University Press, 1976.

http://hdl.handle.net/2027/heb.06531.0001.001 
Frey, Brendan J., and Delbert Dueck. "Clustering by Passing Messages Between Data Points." Science 315 (2007): 972-976. https://doi.org/10.1126/science.1136800

Funk, Kellen, and Lincoln A. Mullen. "A Servile Copy: Text Reuse and Medium Data in American Civil Procedure." In Forum: Die geisteswissenschaftliche Perspektive: Welche Forschungsergebnisse lassen Digital Humanities erwarten? [Forum: With the Eyes of a Humanities Scholar: What Results Can We Expect from Digital Humanities?], Rechtsgeschichte [Legal History] 24 (2016): 341-343.

https://doi.org/10.12946/rg24/341-343

Funk, Kellen, and Lincoln A. Mullen. "The Spine of American Law: Digital Text Analysis and U.S. Legal Practice," American Historical Review 123, no. 1 (2018): 132-164. https://doi.org/10.1093/ahr/123.1.132

Gavin, Michael, Collin Jennings, Lauren Kersey, and Brad Pasanek. "The Force of Language: Vector Semantics, Conceptual History, and Close Reading. In Debates in DH 2019, ed. Matthew K. Gold and Lauren F. Klein, online edition (University of Minnesota Press, forthcoming 2019), http://dhdebates.gc.cuny.edu.

Graham, Shawn, Ian Milligan, and Scott Weingart. Exploring Big Historical Data: The Historian's Macroscope. Hackensack, NJ: Imperial College Press, 2015.

http://www.themacroscope.org/2.0/

Goldstone, Andrew, and Ted Underwood. "The Quiet Transformations of Literary Studies: What Thirteen Thousand Scholars Could Tell Us." New Literary History 45, no. 3 (2014): 359-384. https://doi.org/10.1353/nlh.2014.0025

Hockey, Susan. "The History of Humanities Computing." In A Companion to Digital Humanities, ed. Susan Schreibman, Ray Siemens, and John Unsworth (Blackwell, 2004):

http://digitalhumanities.org:3030/companion/view?docId=blackwell/9781405103 213/9781405103213.xml\&chunk.id=ss1-2-1.

Jockers, Matthew L. Text Analysis with R for Students of Literature. Springer, 2014. http://link.springer.com/10.1007/978-3-319-03164-4.

Jockers, Matthew, and Gabi Kirilloff. "Understanding Gender and Character Agency in the 19th Century Novel." Journal of Cultural Analytics (2016): http://culturalanalytics.org/2016/12/understanding-gender-and-character-agency -in-the-19th-century-novel/, https://doi.org/10.22148/16.010.

Leskovec, Jure, Anand Rajaraman, and Jeff Ullman, Mining of Massive Datasets, 2nd ed. (Cambridge University Press, 2014). http://www.mmds.org/\#ver21

Robinson, David. "K-means Clustering is Not a Free Lunch." Variance Explained, January 16, 2015. http://varianceexplained.org/r/kmeans-free-lunch/. 
Scheinfeldt, Tom. "Sunset for Ideology, Sunrise for Methodology?" In Debates in DH 2012, ed. Matthew K. Gold, online edition (University of Minnesota Press, 2012), http://dhdebates.gc.cuny.edu/debates/text/39.

- - - "Where's the Beef? Does Digital Humanities Have to Answer Questions?" In Debates in DH 2012, ed. Matthew K. Gold, online edition (University of Minnesota Press, 2012), http://dhdebates.gc.cuny.edu/debates/text/18.

Schmidt, Benjamin. "Do digital humanists Need to Understand Algorithms?" In Debates in the Digital Humanities 2016, ed. Matthew K. Gold and Lauren F. Klein, online edition (University of Minnesota Press, 2016), http://dhdebates.gc.cuny.edu/debates/text/99.

Smith, David A., Ryan Cordell, and Abby Mullen. "Computational Methods for Uncovering Reprinted Texts in Antebellum Newspapers." American Literary History 27, no. 3 (September 1, 2015): E1-15. https://doi.org/10.1093/alh/ajv029.

Thomas II, Willam G. "Computing and the Historical Imagination." In A Companion to Digital Humanities, ed. Susan Schreibman, Ray Siemens, and John Unsworth (Blackwell, 2004):

http://digitalhumanities.org:3030/companion/view?docId=blackwell/9781405103 213/9781405103213.xml\&chunk.id=ss1-2-5.

Wolpert, David H., and William G. Macready. "No Free Lunch Theorems for Optimization." IEEE Transactions on Evolutionary Computation 1, no. 1 (April 1997): 67-82. http://ti.arc.nasa.gov/m/profile/dhw/papers/78.pdf. 